\title{
Efficacy of Leeching in Frostbite
}

\section{Iqbal $A^{1 *}$, Jan $A^{2}$, Ali Quraishi $H^{3}$, Islam $N^{4}$, Raheem $A^{5}$ and Rashid $\mathrm{A}^{6}$}

${ }^{1}$ MD Scholar Moalijat, (Research officer-Scientist - III), Regional Research Institute of Unani Medicine, University of Kashmir, India

${ }^{2}$ Assistant Professor Physiology, IAMS, India

\section{Research article}

Volume 4 Issue 4

Received Date: September 24, 2019

Published Date: October 16, 2019

DOI: $10.23880 /$ cdoaj- 16000190

${ }^{3}$ MD.Scholar Moalijat, Regional Research Institute of Unani Medicine, University of Kashmir, India

${ }^{4}$ Prof \& HOD, Moalijat, Regional Research Institute of Unani Medicine, University of Kashmir, India

${ }^{5}$ Research officer Scientist - IV, CCRUM, Ministry of AYUSH, India

${ }^{6}$ Lecturer Government Degree College Ganderbal, India

*Corresponding author: Dr Arsheed Iqbal, M.D. Scholar Unani Medicine (Research Officer, Scientist-III), Regional Research Institute of Unani Medicine, University of Kashmir, Jammu \& Kashmir, Srinagar, India, Tel: 9419078302; Email: drarsheediqbal@gmail.com

\section{Abstract}

Frostbite is a freezing, cold thermal injury, which occurs when tissues are exposed to temperatures below their freezing point for a sustained period of times. Frostbite is commonly found in countries with extreme cold climate and mostly found in military. Now a day's frostbite is found in people associated with winter sports like skiing, hiking, ice climbing. In frostbite two distinct mechanisms, cellular death and necrosis are responsible for dermal ischemia. The extracellular ice crystals are initially formed due to freezing of tissues. These crystals disturb the osmotic gradient of the cell membrane and directly damaging the cell. Causing intracellular dehydration .The intracellular electrolyte concentration increases dramatically initiating cell death. Due to continuous fall in tissue temperature, there is formation of intracellular ice crystals and later theses ice crystals expand leading to mechanical detoration of cells. Anatomically hands and feet account for $90 \%$ of reported injuries, and the others parts involved can be face, buttocks and penis. The role of thromboxane's and prostaglandins has resulted in more active approach to the medical treatment of frostbite. However this study of leeching in frostbite showed outstanding results in the treatment of all forms of frostbite with very low recurrence rate.

Keywords: Frostbite; Leeching; Hirudotherapy

\section{Introduction}

Frostbite is well documented in the military and in countries with extreme temperatures for centuries. The earliest documented evidence of frostbite may be a 5,000year-old pre-Columbian mummy discovered in the Andes [1]. The first report of mass cold injuries was by Baron Larrey, Surgeon-in-Chief to Napoleon's Army throughout 
the invasion of Russia during the winter of 1812-1813 [2]. More recent descriptions of cold injury have centered around military campaigns, from Xenophon's writings of 210 BC [3] to Dr. James Thatcher's reports during the American Revolution [4] and cases from the Korean and Falklands wars. Baron Dominique Larrey, Napoleon's military surgeon, gave the first description of the pathophysiology of frostbite during the infamous 1812 retreat from Moscow [5]. He wrote: "The natural heat is absorbed and a discharge of caloric takes place, the pores close and the capillary vessels fall into a state of contraction; the fluids are condensed and flow more slowly." Larrey introduced the concept of friction massage with ice or snow and was the first to describe the similarities to burns. The extreme effects of cold on ground troops were again seen during the world wars of the 20th century. Many of these injuries were sustained at non-freezing temperatures and, although similar to frostbite, were caused by prolonged immersion in cold water $\left(1.6^{\circ} \mathrm{C}-4.4^{\circ} \mathrm{C}\right)$. This led to the term "trench foot" $[3,6]$ or "immersion foot"[7]. Cold injury, however, was not limited to ground troops. High-altitude frostbite, first described in 1943, was recognized from the treatment of aviators during World War II. In fact, heavy bomber crews sustained more injuries from frostbite than from all other causes combined [7].

\section{Pathophysiology}

Two distinct mechanisms are apparently responsible for tissue injury: (1) cellular death occurring at the time of exposure to the cold, and (2) deterioration and necrosis attributable to progressive dermal ischemia [8-10]. Freezing of tissue leads initially to the formation of extracellular ice crystals. These crystals directly damage the cell membrane and change the osmotic gradient across it, resulting in intracellular dehydration [11]. The intracellular electrolyte concentration increases dramatically and initiating cell death. As the temperature of the tissue continues to fall, intracellular ice forms. These ice crystals expand, causing the mechanical destruction of cells [12].

\section{Material and Methods}

Leech was applied to 40 patients of clinically diagnosed frostbite. The patients with frostbite in feet were only selected for study. The study was done in coldest months of the year at RRIUM, Srinagar from November to February. All the base line investigations including electrolytes were done before the study. The patients were given six sittings of leech therapy every after one week to both the feet. The part to which the leech was applied was hygienically prepared. Six leeches were applied on each foot for a period of at least 40 minutes or till they terminate of their own. The wounds were allowed to bleed at least for one hour and then an antiseptic dressing was applied and was kept for 12 hours. The patients were continuously monitored for any type of allergic reaction or infection. After completing the six sittings of leech therapy the patients were fallowed up for complete one year.

\section{Clinical Manifestations}

Frostbite has been categorized into four degrees. In first-degree frostbite, there is a numb central white plaque with surrounding erythema. Second degree injury causes blister formation surrounded by erythema and oedema. These blisters fill with clear or milky fluid in the first twenty four hours. Third degree injury is characterized by haemorrhagic blisters that result in a hard black eschar two weeks later. Fourth degree injury produces complete necrosis and tissue loss. In the long term, cold sensitivity, sensory loss, and hyperhidrosis may persist in the affected part for years [13]. Less commonly, growth plate disturbances [14,15], osteoarthritis [16], chronic pain [14], and heterotopic calcification have also been reported [17].

\section{Radiological Assessment of Tissue Injury}

Several radiologic techniques have been applied to this problem in an attempt to provide an accurate early assessment of tissue viability. These include plain radiographs, venous radioisotope scanning (131I, 133Xe, and $99 \mathrm{Tc}$ ), angiography, and digital plethysmography for assessment of tissue perfusion. Plain radiographs may be helpful in the assessment of frostbitten extremities. Early radiographic manifestations include soft tissue swelling and loss of tissue, especially at the tips of the digits, osteoporosis and periosteitis may occur at a slightly later stage [17]. In the early stages, arteriography demonstrates marked slowing of blood flow in sizeable branches. As rewarming occurs, arterial flow improves but residual occlusions are often noted [18]. Angiography has been used in the diagnosis and treatment of cold injury, although arteriograms obtained soon after injury do not sufficiently clarify levels of viability [6]. Laser Doppler flowmetry appears to offer accurate assessment of vasomotor status [19], Technetium scintigraphy has become the standard imaging study used within the first few days after injury [20-22]. Use of this technique has been suggested to assess tissue viability in an effort to 
allow earlier debridement of soft tissue and coverage of ischemic bony structures [23,24]. Some authors are now advocating magnetic resonance imaging and magnetic resonance angiography as superior techniques. These techniques, by allowing direct visualization of occluded vessels and imaging of the surrounding tissues and by showing a more clear-cut line of demarcation of ischemic soft tissue, may make earlier surgical intervention possible.

\section{Pre Hospital Care and Prevention}

Prevention is always important for less exposure by way of educating people for wearing worm cloths, socks etc. before the onset of the winter, avoiding contact with cold water, snow etc. and not to walk bear footed. Those working with equipment that uses coolant such as liquid nitrogen or carbon dioxide should have adequate education in safe handling be moved out of wind. Warm the cold extremities by placing in a companions armpit or groin for ten minutes. After sensation the patients may start walking and if at high altitude supplementary oxygen should be considered. Aspirin $75 \mathrm{mg}$ can be given for its rheological effect. Ibuprofen $12 \mathrm{mg} / \mathrm{kg} /$ day divided in two doses may be given for its prostaglandin effect.

\section{Hospital Management}

Immediate and general care for those admitted with frostbite: Underlying unstable co morbidities, trauma or hypothermia must be assessed and managed before frostbitten extremities are treated. Moderate or severe hypothermia should be corrected to bring core temperature above $35^{\circ} \mathrm{C}$ before initiating frostbite warming $[25,26]$. Remove jewelry from affected digits as early as possible, because significant swelling can be expected post thaw, and vascular compromise may occur with tight rings, etc [25].

Fluids: Rehydration can be oral or intravenous, and depending upon severity and ability of the patient to tolerate oral fluids. High altitude increases the risk of dehydration. If the patient is also hypothermic, dehydration may be compounded by cold diuresis due to suppression of antidiuretic hormone, requiring correction with warmed intravenous fluid.

Imaging: For deep injuries, no surgical debridement should be planned until imaging is performed. Many modalities have been used, but angiography and technecium99 (99Tc) triple phase bone scanning give the best prognostic information and will direct therapy [27].
Rewarming: Rewarming is beneficial if there remains a partially or fully frozen part and is ideally accomplished using a whirlpool bath set at $38^{\circ} \mathrm{C}$ with added antiseptic solution (povidone iodine or chlorhexidine) $[25,28]$. The time period for optimal rewarming varies from 15-30 min up to $1 \mathrm{~h}$ [29]. Rewarming should continue until a red/purple colour appears and the extremity tissue becomes pliable [25]. Active motion during the rewarming process is beneficial.

Blisters and dressing: note the type of any blisters that can be clear/cloudy or hemorrhagic in nature. The recommended practice is that of selective drainage of clear/cloudy blisters by needle aspiration and to leave hemorrhagic blisters alone [25]. All blisters are debrided in the hospital. Topical aloe Vera cream or gel (a potent anti-prostaglandin agent) should then be applied to thawed tissue before dressings are applied [25]. Splinting, elevating and wrapping the affected part in a loose, protective dressing with padding between affected patient's digits are ideal.

Antibiotics: The role of prophylactic antibiotics is not proven but should be considered in more severe injuries (grades 3 and 4) and, in particular, when associated with significant edema or malnutrition. Systemic antibiotics are required in the presence of proven infection, trauma or cellulites.

Analgesia and NSAIDS: Rewarming the extremities can become extremely painful, so use of non-steroidal antiinflammatory drugs or opiates should be administered. Oral ibuprofen $12 \mathrm{mg} / \mathrm{kg}$ divided over two daily doses provides systemic anti-prostaglandin activity that limits the cascade of inflammatory damage. This dose can be increased to a maximum of $2,400 \mathrm{mg} /$ day if the patient is experiencing pain and can be continued until wounds are healed or amputation occurs. A dose of $400 \mathrm{mg}$ BID is a practical regime on which to start most patients and this can then be increased to $600 \mathrm{mg}$ QDS as pain dictates. If aspirin has not been given in the field (providing no contraindications), $300 \mathrm{mg}$ once a day can be given [30].

\section{Angiography and Thrombolysis}

An initial selective diagnostic digital subtraction angiography should be performed in patients being considered for thrombolysis. Intravenous vasodilators (nitroglycerin or papaverine) are useful (in conjunction with TPA) at this stage in the treatment of the vasospasm that often accompanies a frostbite injury [26,31,32]. 


\section{Classification}

\begin{tabular}{|c|c|c|c|c|}
\hline $\begin{array}{c}\text { Frostbite injuries of the } \\
\text { extremity }\end{array}$ & Grade 1 & Grade 2 & Grade 3 & Grade 4 \\
\hline $\begin{array}{c}\text { Extent of initial lesion at day } \\
0 \text { after rewarming }\end{array}$ & $\begin{array}{l}\text { Absence of } \\
\text { initial lesion }\end{array}$ & $\begin{array}{c}\text { Initial lesion on } \\
\text { distal phalanx }\end{array}$ & $\begin{array}{c}\text { Initial lesion on } \\
\text { intermediary (and) } \\
\text { proximal phalanx } \\
\end{array}$ & $\begin{array}{l}\text { Initial lesion on } \\
\text { carpal/tarsal }\end{array}$ \\
\hline Bone scanning at day 2 & Useless & $\begin{array}{l}\text { Hypofixation of } \\
\text { radiotracer } \\
\text { uptake area }\end{array}$ & $\begin{array}{l}\text { Absence of radiotracer } \\
\text { uptake on the digit }\end{array}$ & $\begin{array}{c}\text { Absence of radiotracer } \\
\text { uptake } \\
\text { area on the } \\
\text { carpal/tarsal region }\end{array}$ \\
\hline Blisters at day 2 & $\begin{array}{l}\text { Absence of } \\
\text { blisters }\end{array}$ & Clear blisters & $\begin{array}{l}\text { Hemorrhagic blisters } \\
\text { on the digit }\end{array}$ & $\begin{array}{c}\text { Haemorrhagic blisters } \\
\text { over carpal/tarsal } \\
\text { region }\end{array}$ \\
\hline \multirow[b]{2}{*}{ Prognosis at day 2} & No amputation & $\begin{array}{c}\text { Tissue } \\
\text { amputation }\end{array}$ & Bone amputation of digit & $\begin{array}{l}\text { Bone amputation of the } \\
\text { limb }\end{array}$ \\
\hline & No sequelae & $\begin{array}{l}\text { Fingernail } \\
\text { sequelae }\end{array}$ & Functional sequelae & $\begin{array}{c}+/- \text { systemic } \\
\text { involvement } \\
+/- \text { sepsis functional } \\
\text { sequelae }\end{array}$ \\
\hline
\end{tabular}

Table 1: Classification scheme for the severity of frostbite injury [33].

Distribution of Patients

\begin{tabular}{|c|c|c|c|}
\hline S. No. & Age Group & Number of Patients & Percentage of Patients \\
\hline $\mathbf{1}$ & 10-20 years & 23 & 57 \\
\hline $\mathbf{2}$ & $21-30$ years & 11 & 28 \\
\hline $\mathbf{3}$ & 31-40 years & 06 & 15 \\
\hline
\end{tabular}

Table 2: According to age group.
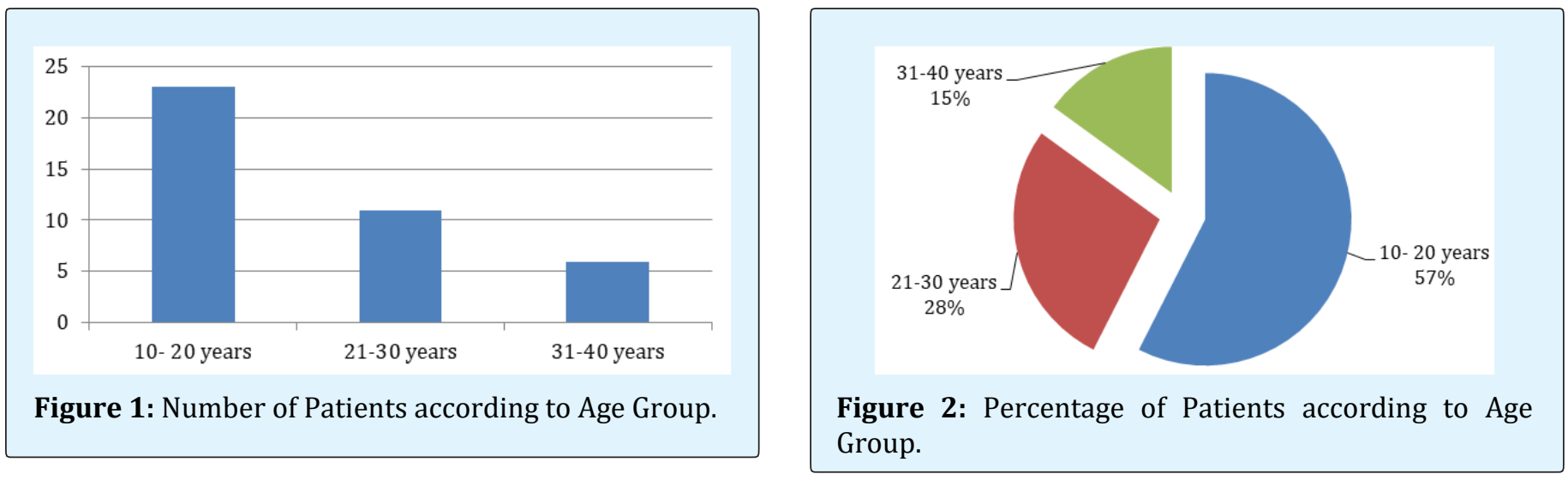

\begin{tabular}{|c|c|c|c|}
\hline S. No. & Mizaj (Temperament) & Number of Patients & Percentage of Patients \\
\hline $\mathbf{1}$ & Damwi & 12 & 30 \\
\hline $\mathbf{2}$ & Safrawi & 02 & 05 \\
\hline $\mathbf{3}$ & Balghami & 19 & 48 \\
\hline $\mathbf{4}$ & Saudawi & 07 & 17 \\
\hline
\end{tabular}

Table 3: According to Mizaj (Temperament). 


\section{Clinical Dermatology Open Access Journal}

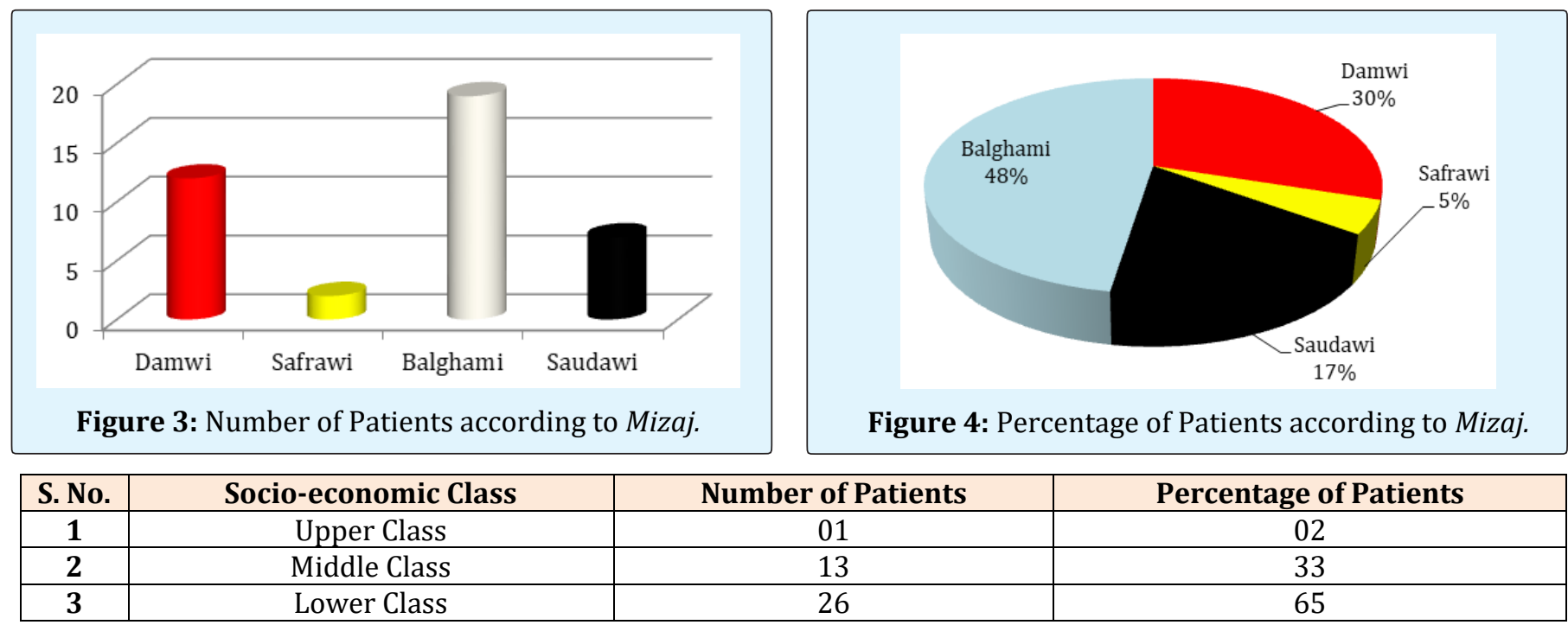

Table 4: According to Socio-economic Status of Family.

\begin{tabular}{|c|c|c|c|c|}
\hline & \multicolumn{2}{|c|}{} \\
\hline
\end{tabular}

Table 5: According to Gender.

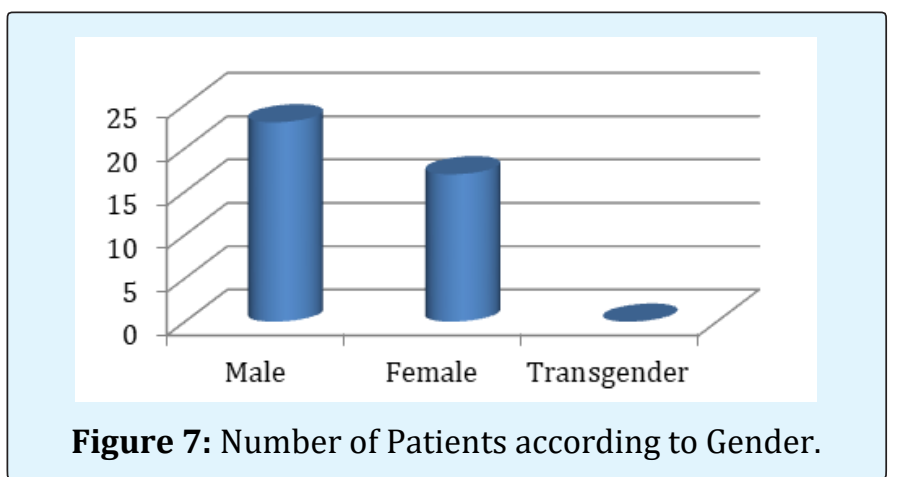

Iqbal A, et al. Efficacy of Leeching in Frostbite. Clin Dermatol J 2019, 4(4): 000190.

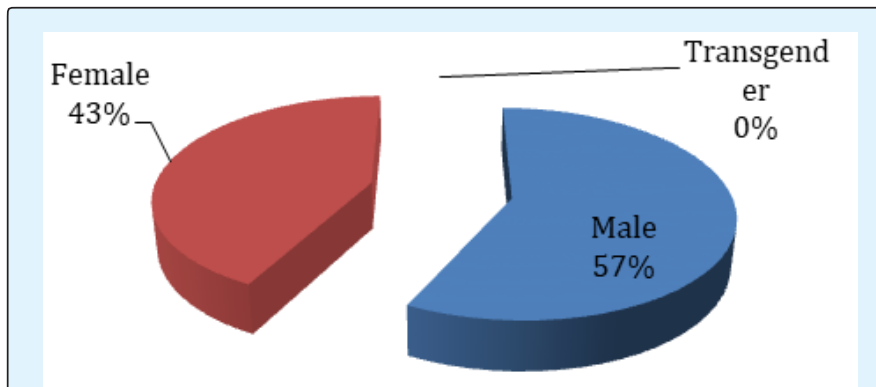

Figure 8: Percentage of Patients according to Gender. 


\begin{tabular}{|c|c|c|c|}
\hline S. No. & Clinical features & Number of Patients & Percentage of Patients \\
\hline $\mathbf{1}$ & Redness & 11 & 27 \\
\hline $\mathbf{2}$ & Itching & 13 & 32 \\
\hline $\mathbf{3}$ & Ulcer & 06 & 15 \\
\hline $\mathbf{4}$ & Redness + Itching & 04 & 10 \\
\hline $\mathbf{5}$ & Redness + Itching + Ulcer & 03 & 8 \\
\hline $\mathbf{6}$ & Itching + Ulcer & 03 & 8 \\
\hline
\end{tabular}

Table 6: According to Clinical feature.
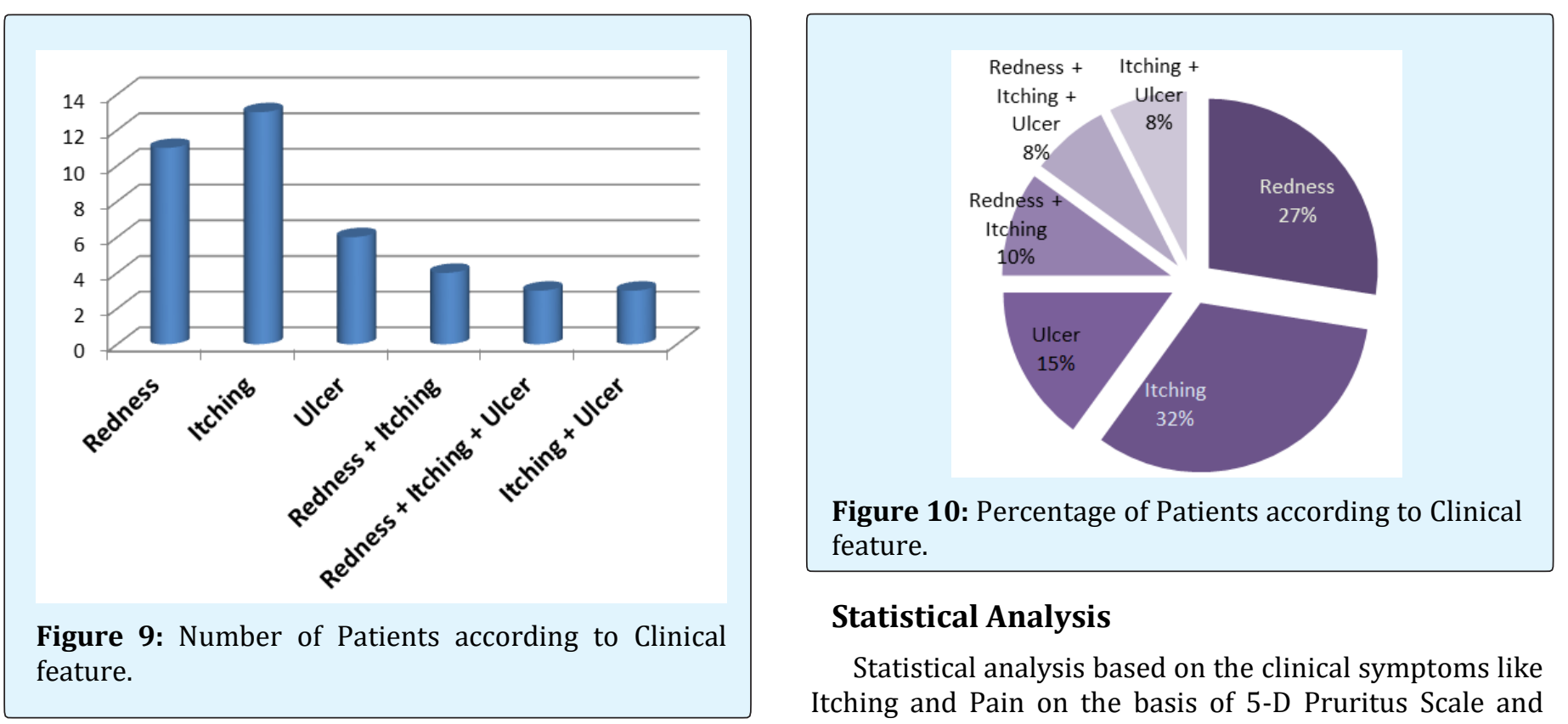

\section{Statistical Analysis}

Statistical analysis based on the clinical symptoms like Itching and Pain on the basis of 5-D Pruritus Scale and VAS Scale.

\begin{tabular}{|c|c|c|c|c|}
\hline $\begin{array}{c}\text { Patients S. } \\
\text { No. }\end{array}$ & \multicolumn{2}{|c|}{ 5-D Pruritus Scale Score } & \multicolumn{2}{c|}{ VAS Scale Score } \\
\hline & Before Treatment & After Treatment & Before Treatment & After Treatment \\
\hline $\mathbf{1}$ & 34 & 9 & 6 & 2 \\
\hline $\mathbf{2}$ & 33 & 7 & 5 & 2 \\
\hline $\mathbf{3}$ & 31 & 5 & 5 & 1 \\
\hline $\mathbf{4}$ & 30 & 4 & 4 & 1 \\
\hline $\mathbf{5}$ & 35 & 4 & 5 & 1 \\
\hline $\mathbf{6}$ & 33 & 5 & 4 & 1 \\
\hline $\mathbf{7}$ & 34 & 6 & 6 & 1 \\
\hline $\mathbf{8}$ & 31 & 4 & 5 & 1 \\
\hline $\mathbf{9}$ & 32 & 4 & 4 & 1 \\
\hline $\mathbf{1 0}$ & 33 & 8 & 6 & 2 \\
\hline $\mathbf{1 1}$ & 28 & 5 & 7 & 2 \\
\hline $\mathbf{1 2}$ & 32 & 4 & 8 & 2 \\
\hline $\mathbf{1 3}$ & 26 & 5 & 6 & 2 \\
\hline $\mathbf{1 4}$ & 22 & 4 & 7 & 2 \\
\hline $\mathbf{1 5}$ & 29 & 5 & 8 & 1 \\
\hline $\mathbf{1 6}$ & 27 & 4 & 8 & \\
\hline
\end{tabular}




\begin{tabular}{|l|l|l|l|l|}
\hline $\mathbf{1 7}$ & 31 & 5 & 8 & 9 \\
\hline $\mathbf{1 8}$ & 35 & 4 & 6 & 1 \\
\hline $\mathbf{1 9}$ & 30 & 6 & 7 & 1 \\
\hline $\mathbf{2 0}$ & 28 & 5 & 8 & 1 \\
\hline $\mathbf{2 1}$ & 31 & 4 & 7 & 1 \\
\hline $\mathbf{2 2}$ & 29 & 6 & 7 & 2 \\
\hline $\mathbf{2 3}$ & 27 & 4 & 7 & 2 \\
\hline $\mathbf{2 4}$ & 26 & 5 & 6 & 2 \\
\hline $\mathbf{2 5}$ & 29 & 6 & 6 & 1 \\
\hline $\mathbf{2 6}$ & 25 & 4 & 8 & 2 \\
\hline $\mathbf{2 7}$ & 20 & 7 & 8 & 1 \\
\hline $\mathbf{2 8}$ & 21 & 5 & 8 & 1 \\
\hline $\mathbf{2 9}$ & 24 & 4 & 7 & 1 \\
\hline $\mathbf{3 0}$ & 27 & 5 & 6 & 1 \\
\hline $\mathbf{3 1}$ & 26 & 6 & 5 & 1 \\
\hline $\mathbf{3 2}$ & 25 & 4 & 7 & 1 \\
\hline $\mathbf{3 3}$ & 22 & 5 & 5 & 1 \\
\hline $\mathbf{3 4}$ & 29 & 6 & 8 & 1 \\
\hline $\mathbf{3 5}$ & 19 & 4 & 8 & 1 \\
\hline $\mathbf{3 6}$ & 22 & 4 & 8 & 1 \\
\hline $\mathbf{3 7}$ & 21 & 4 & 7 & 1 \\
\hline $\mathbf{3 8}$ & 35 & 4 & 7 & 1 \\
\hline $\mathbf{3 9}$ & 33 & 4 & 6 & \\
\hline $\mathbf{4 0}$ & 34 & 4 & & \\
\hline
\end{tabular}

Table 7: 5-D pruritus and VAS score before and after the therapy.

\begin{tabular}{|c|c|c|}
\hline Table Analyzed & Based on 5-D Pruritus Scale Score & Based on VAS Score \\
\hline \multicolumn{3}{|l|}{ Before } \\
\hline Vs & Vs & Vs \\
\hline \multicolumn{3}{|l|}{ After } \\
\hline Test Applied & Paired $\mathbf{t}$ test & Paired $\mathbf{t}$ test \\
\hline $\mathrm{P}$ value & $<0.0001$ & $<0.0001$ \\
\hline P value summary & $* * *$ & $* * *$ \\
\hline Are means signif. Different? $(\mathrm{P}<0.05)$ & Yes & Yes \\
\hline One- or two- tailed P value? & Two-tailed & Two-tailed \\
\hline $\mathrm{T}, \mathrm{df}$ & $\mathrm{t}=32.57 \mathrm{df}=39$ & $\mathrm{t}=24.91, \mathrm{df}=39$ \\
\hline Number of pairs & 40 & 40 \\
\hline \multicolumn{3}{|l|}{ How big is the difference? } \\
\hline Mean of differences & 23.53 & 5.275 \\
\hline 95\% confidence interval & 22.06 to 24.99 & 4.847 to 5.703 \\
\hline R squared & 0.9645 & 0.9408 \\
\hline
\end{tabular}

Table 8: Statistical analysis on 5-D pruritus and VAS score pre and post treatment.

From the statistical analysis we found that there is a strong significant difference between the clinical parameters based on 5-D Pruritus scale and VAS score before and after the leech therapy. So, practitioners are advised to use the leeching therapy to deal with frostbite cases.

Iqbal A, et al. Efficacy of Leeching in Frostbite. Clin Dermatol J 2019, 4(4): 000190.

\section{Results}

Clinically leech therapy (Hirudotherapy) proved highly efficacious by reducing the local inflammation, decreasing the edema, itching and enhanced the healing process. From the statistical analysis we found that there is a strong significant difference between the clinical 
parameters based on 5-D Pruritus scale and VAS score before and after the leech therapy. So, practitioners / Physicians are advised to use the leeching therapy to treaty/ Recommend with frostbite cases.

\section{Discussion}

Leeching help in removing the toxins from the blood by improving the deranged humours and enhancing the blood perfusion infusing healthy bioactive enzymes in to the body and thus modulating the body to heal itself. The Hirudotherapy (Leeching) help to maintain vascular patency and improve their health there by regulate the blood circulation by way of peptides and proteins of leech salivary secretion. Hirudotherapy transmits enzymes like hyaluronidase that enhance the viscosity of the interstitial fluid. It has acetylcholine and histamine like substances as well as carboxypeptidase A inhibitors which can increase flow by dilating constricted vessels. Calin is an important bioactive substance that inhibits the coagulation and another component named as destabilase dissolve fibrin clots and as well as inhibits the formation of thrombus. The leeches have some important enzymes that removes infected blood and releases some therapeutic components that help in resolving the inflammation reducing the pain and healing the wounds. These bioactive substances thus help in healing frostbite wounds and to resolves the associated inflammatory conditions.

\section{Conclusion}

Deep frostbite is a serious condition that is associated with significant morbidity, and it is becoming more frequent in young active individuals who put themselves at risk like prolonged hiking and snow skating. Timely pre-hospital and definitive hospital management are important to minimize final tissue loss and maximize functionality of the affected limb. Surgeons should not rush for early amputation. We have outlined a series of management frameworks, which we hope will enable surgeons who rarely see this condition to have a greater understanding of frostbite and its management. Either intravenous iloprost or thrombolysis with rTPA should be considered in all patients who present within 24 hours of sustaining an appropriately severe injury and if the facility is capable of appropriate administration and monitoring. Both treatments should be started as soon as it is practical to gain maximal benefit. There is some evidence iloprost can be used beyond the 24 hour window and it is the treatment of choice where there are contraindications to thrombolysis. Bone scanning is helpful to ascertain deep tissue injury and response to therapy. If iloprost is an available option, then iloprost is the preferred option based upon its simplicity of administration, safety and efficacy. Prevention with education, behaviour modification and appropriate use of suitable equipment is important to reduce frostbite incidence. The saliva of Medicinal leech contains a powerful anticoagulant, a vasodilator, a spreading factor, enzymes and an anesthetic. The anticoagulant prevents blood from clotting. The vasodilator opens up blood vessels helping to increase blood flow. An anesthetic is pumped into bite from minute ducts between its teeth. This makes a leech bite painless. The spreading factor moves all chemical quickly into tissue farthest from the bite, liquefying any hardening blood and in this way these bioactive substances help in healing frostbite wounds and to resolve the associated inflammatory conditions.

\section{Acknowledgement}

Authors duly acknowledge the Assistant Director In Charge and Hospital staff of Regional Research Institute of Unani Medicine, University of Kashmir, Srinagar.

\section{References}

1. Post PW, Donner DD (1972) Frostbite in a preColumbian mummy. Am J Phys Anthropol 37(2): 187191.

2. Larrey DJ, Hall RW (1987) Memoirs of Military Surgery, 1st American edition from the $2^{\text {nd }}$ (Edn.) Joseph Cushing: Baltimore-1814.

3. Schechter DC, Sarot RA (1968) Historical accounts of injuries due to cold. Surgery 63: 527-533.

4. Vogel JE, Dellon AL (1989) Frostbite injuries of the hand. Clin Plast Surg 16(3): 565-576.

5. Larrey DJ. Memoirs of Military Surgery and Campaigns of the French Armies. Baltimore: Cushing; 1814: 156-164.

6. Purdue GF, Hunt JL (1986) Cold injury: a collective review. J Burn Care Rehabil 7(4): 331-342.

7. Dembert ML, Dean LM, Noddin EM (1981) Cold weather morbidity among US Navy and Marine Corps personnel. Mil Med 146(11): 771-775.

8. Weatherly-White RCA, Sjostrom B, Paton BC (1964) Experimental studies in cold injury II: the pathogenesis of frostbite. J Surg Res 4: 17-22. 
9. Weatherly-White RCA, Paton BC, Sjostrom B (1965) Experimental studies in cold injury III: observations on the treatment of frostbite. Plast Reconstr Surg 36(1): 10-18.

10. Quintanilla R, Krusen FH, Essex HE (1947) Studies on frostbite with special reference to treatment and the effect on minute blood vessels. Am J Physiol 149(1): 149-161.

11. Bracker MD (1992) Environmental and thermal injury. Clin Sports Med 11(2): 419-436.

12. Heggers JP, Robson MC, Manavalen K, Weingarten MD, Carethers JM, et al. (1987) Experimental and clinical observations on frostbite. Ann Emerg Med 16(9): 1056-1062.

13. Edlich RF, Chang DE, Birk KA, Morgan RF, Tafel JA (1989) Cold injuries. Compr Ther 15: 13-21.

14. Britt LD, Dascombe WH, Rodriguez A (1991) New horizons in management of hypothermia and frostbite injury. Surg Clin North Am 71(2): 345-370.

15. Reed MH (1988) Growth disturbances in the hands following thermal injuries in children, II: frostbite. Can Assoc Radiol J 39: 95-99.

16. Rompe G (1988) Unilateral finger polyarthrosis as a late sequel of frostbite. Z Orthop 126(3): 358-360.

17. Sutton D (1993) A Textbook of Radiology and Imaging. London: Churchill Livingstone 1993: 212350.

18. Gralino BJ, Porter JM, Rosch J (1976) Angiography in the diagnosis and therapy of frostbite. Radiology 119(2): 301-305.

19. Fleischmann W, Becker U, Bischoff M, Hoekstra $H$ (1995) Vacuum sealing: indications, technique and results. Eur J Orthop Surg Traumatol 5(1): 37-40.

20. Ikawa G, dos Santos PA, Yamaguchi KT, Ibello R (1986) Frostbite and bone scanning: the use of $99 \mathrm{~m}$ labelled phosphates in demarcating the line of viability in frostbite victims. Orthopedics 9(9): 12571261.

21. Salimi Z (1985) Frostbite. Assessment of tissue viability by scintigraphy. Postgrad Med 77(1): 133134.

22. Lisbona R, Rosenthall L (1976) Assessment of bone viability by scintiscanning in frostbite injuries. J Trauma 16(12): 989-992.

Iqbal A, et al. Efficacy of Leeching in Frostbite. Clin Dermatol J 2019, 4(4): 000190.
23. Mehta RC, Wilson MA (1989) Frostbite injury: prediction of tissue viability with triple-phase bone scanning. Radiology 170: 511-514.

24. Salimi Z, Wolverson MK, Herbold DR, Vas W (1986) Frostbite: experimental assessment of tissue damage using Tc-99m pyrophosphate. Radiology 161(1): 227231.

25. McIntosh SE, Hamonko M, Freer L, Grissom CK, Auerbach PS, et al. (2011) Wilderness Medical Society: Wilderness Medical Society practice guidelines for the prevention and treatment of frostbite. Wild Environ Med 22(2): 156-166.

26. Sheridan RL, Goldstein MA, Stoddard FJ Jr, Walker TG (2009) Case records of the Massachusetts General Hospital. Case 41-2009. A 16-year-old boy with hypothermia and frostbite. New Engl J Med 361(27): 2654-2662.

27. Gross EA, Moore JC (2012) Using thrombolytics in frostbite injury. J Emerg Trauma Shock 5(3): 267-271.

28. Murkowski FH, Mandsager R, Choromanski Hull-Jilly D (2003) State of Alaska Cold Injuries Guidelines. Juneau: Department of Health and Social Services of Alaska 36-41.

29. McCauley RL, Hing DN, Robson MC, Heggers JP (1983) Frostbite injuries: a rational approach based on the pathophysiology. J Trauma 23(2): 143-147.

30. Hallam MJ, Cubison T, Dheansa B, Imray C (2010) Managing frostbite. BMJ 341: c5864.

31. Edmonson GR, Bretzman PA, Mohr WJ, Ahernholtz DH (2008) Intra-arterial thrombolytic therapy for limb salvage in severe frostbite. J Vasc Interv Radiol 19(2): 21-22.

32. Saemi AM, Johnson JM, Morris CS (2009) Treatment of bilateral hand frostbite using transcatheter arterial thrombolysis after papaverine infusion. Cardiovasc Intervent Radiol 32(6): 1280-1283.

33. Cauchy E, Marsigny B, Allamel G, Verhellen R, Chetaille E (2000) The value of technetium 99 scintigraphy in the prognosis of amputation in severe frostbite injuries of the extremities: a retrospective study of 92 severe frostbite injuries. J Hand Surg 25(5): 969-978.

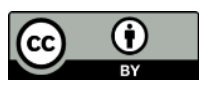

